\title{
Terminologia położnicza w polskich drukowanych podręcznikach akuszerii i anatomii z II połowy XVIII wieku
}

Słowa kluczowe: położnictwo; polska terminologia położnicza; historia medycyny; XVIII wiek

W XVIII w. zaczęto wyodrębniać położnictwo jako niezależną od chirurgii naukę. Odbieranie porodów dostępne tylko kobietom, z reguły opierających wiedzę na doświadczeniu, zaczęto postrzegać jako element wiedzy medycznej dostępnej także wykształconym mężczyznom. Lekarze zaczęli nawoływać do szkolenia „babek wiejskich” oraz zakładania dla nich szkół, a studentów medycyny do nauki położnictwa ${ }^{2}$. Polacy, na wzór wypracowanych na zachodzie Europy metod odbierania porodu, zaczęli pisać podręczniki w języku polskim³ ${ }^{3}$. Chciano w ten sposób uzupełnić brak lekarzy-położników w Polsce, ale i zmienić postępowanie bab. Zaczęto opisywać i nazywać części

${ }^{1}$ Instytut Historii, Uniwersytet Zielonogórski, Zielona Góra, e-mail: h.kurowska@ ih.uz.zgora.pl, ORCID: 0000-0002-8885-6449.

2 Z. Słomko, E. Waszyński, Rozwój ginekologii. Od empirii do nauki, [w:] Ginekologia. Podręcznik dla lekarzy i studentów, Z. Słomko (red.), Warszawa 1997, s. 32.

${ }^{3}$ Literatura polskojęzyczna opisująca zabiegi w czasie porodu, jakie mogła czynić baba, znana była od XV w., ale nie zawierała dokładnych opisów anatomii kobiety, o czym mowa dalej. Wykaz tej literatury m.in. w Encyklopedyji powszechnej, t. 1, Warszawa 1859, pod hasłem Akuszeryja, s. 291-294; por. E. Waszyński, Historia położnictwa i ginekologii w Polsce, Wrocław 2012, s. 359-360. 
budowy ciała kobiety, opisywano etapy porodu i klasyfikowano je, a to wymagało stworzenia polskiej terminologii. Język ten musiał być równocześnie zrozumiały dla odbierających porody, w tym dla kobiet.

Celem artykułu jest opisanie różnorodności terminów położniczych i tym samym systematyzacja specjalistycznego języka zawartego $\mathrm{w}$ drukowanych XVIII-wiecznych podręcznikach położniczych i anatomicznych ${ }^{4}$. Analizowane prace zaliczono do grupy podręczników ze względu na adresatów (studenci, kursantki) i poruszaną w nich specjalistyczną problematykę, a także by odróżnić je od popularnych wówczas poradników medycznych. Ewolucja słownictwa medycznego została przedstawiona w licznych pracach naukowych ${ }^{5}$, nie powstała jednak odrębna praca poświęcona kształtowaniu się polskiej nomenklatury położniczej. W artykule zostanie ukazany wachlarz terminów dotyczących układu rodnego kobiety oraz ciąży, jej przebiegu oraz porodu za pomocą metody analizy i krytyki piśmiennictwa.

Pierwszą polską drukowaną pracą poświęconą w całości położnictwu była Sztuka babienia ku nieuchronney dzieci przy porodzie od-

${ }^{4} \mathrm{~W}$ artykule brakuje omówienia m.in. prac prof. Rafała Czerwiakowskiego i dr. Mikołaja Regniera. R. Czerwiakowski, anatom, chirurg i położnik, zwany ojcem polskiego położnictwa. Studiował za granicą. Od 1779 r. wykładowca chirurgii i położnictwa w Szkole Głównej Koronnej. Autor prac położniczych zachowanych w rękopisie: „Nauka połogowania dla niewiast” 1780, „Prawidła położnictwa dla cerulików” 1781, „O położnictwie w powszechności” 1784 czy „Gruntowne początki sztuki położniczej” 1784. Z pewnością prowadzone przez niego przez ponad 20 lat wykłady w języku polskim znalazły odbicie w stosowaniu określonej terminologii przez jego studentów. Zob. Z. Skibiński, Rafał Józef Czerwiakowski. Prof. anatomji w Uniwersytecie Jagiellońskim od 1779 r. do 1782 r., „Archiwum Historii i Filozofii Medycyny” (dalej: AHiFM) 1924, t. 1, z. 3-4; E. Waszyński, Ginekologia i położnictwo, [w:] Dzieje medycyny w Polsce, t. 1, Od czasów najdawniejszych do roku 1914, W. Noszczyk (red.), Warszawa 2015, s. 359-360. M. Regnier, chirurg, studiował we Francji, wykładowca w Wilnie, zachowane rękopisy dot. położnictwa: „Zbiór lekcji i traktatów o akuszerii i jego historii” (1. 80. XVIII w.), „Zbiór lekcji i traktatów o akuszerii” 1785/1786, „Kurs lekcji o akuszerii” 1788/1789 i 1789/1790; za: B. Urbanek, Zapomniana spuścizna naukowa Mikołaja Regniera, „Kwartalnik Historii Nauki i Techniki” 1992, nr 3, s. 113; I. Szybiak, Regnier Mikołaj, [w:] Polski Stownik Biograficzny, t. 30, Warszawa 1987, s. 738-739; M. Stawiak-Ososińska, Kształcenie akuszerek w Wilnie w czasach Szkoły Głównej Wielkiego Księstwa Litewskiego i Szkoły Głównej Litewskiej (1780-1803), „Rocznik Andragogiczny” 2015, t. 22, s. 332-333.

5 J. Majer, F. Skobel, Uwagi nad niektóremi wyrazami lekarskiemi, „Powszechny Pamiętnik Nauk i Umiejętności” 1835, nr 3; R. Wierzbicki, Historia słownictwa lekarskiego polskiego, „AHiFM” 1924, t. 1; J. Ross, Z dziejów polskiego słownictwa lekarskiego, „Język Polski” 1965, nr 4; B. Neumann, Rys dziejów mianownictwa lekarskiego i jego kryzys wspótczesny, „AHiFM” 1968, t. 31, nr 2; J. Masłowski, Polskie słownictwo lekarskie, Wrocław 1977; F. Wysocka, Ksztattowanie sie polskiej terminologii anatomicznej do poczattków XIX w., „Medycyna Nowożytna. Studia nad Historią Medycyny” 1995 , nr 2. 
Terminologia położnicza w polskich drukowanych podręcznikach akuszerii...

bieraiacych Potrzebie a niemniey y ku milemu rodzacych pożytkowi krotko y doskonale zebrana przez I.M.C.P. Jakoba Kostrzewskiego wyzwolonych nauk y filozofii doktora za dokładnym JCKM rozkazem, wydana we Lwowie w $1774 \mathrm{r}$. To właśnie w tym mieście najszybciej rozwinęło się nowożytne położnictwo, tutaj też w 1773 r. powstała szkoła położnych przy Collegium Medicum ${ }^{6}$. J. Kostrzewski napisał tę pracę, będąc studentem medycyny w Wiedniu, gdzie dynamicznie rozwijała się nauka położnicza ${ }^{7}$. Dyrektor studium medycznego Anton von Störck w 1773 r. polecił mu napisanie podręcznika położnictwa i to w języku polskim (od $1772 \mathrm{r}$. Lwów znajdował się w granicach państwa austriackiego). Jednak Sztuka babienia nie stała się podręcznikiem, gdyż w 1776 r. nakazano mu przetłumaczyć na język polski pracę położnika Rafała Steidelego i to ona została zatwierdzona jako podręcznik ${ }^{8}$. Księgę O Sztuce Babienia wydano także we Lwowie w 1777 r., oddzielnie dołączono ilustracje, które według M. Zieleniewskiego były niezbyt czytelne ${ }^{9}$. Drugie wydanie zawierało, jako jedyne XVIII-wieczne dzieło, ryciny ilustrujące układ rodny kobiety oraz ułożenie płodu $\mathrm{w}$ macicy ${ }^{10}$. Warto $\mathrm{w}$ tym miejscu nadmienić, że polecenia przetłumaczenia dzieła nie podjął się bardziej doświadczony Jędrzej Krupiński ${ }^{11}$, a J. Kostrzewski obok Rafała Czerwiakowskiego

${ }^{6}$ E. Waszyński, Ginekologia..., dz. cyt., s. 362.

7 S. Brzozowski, Kostrzewski Jakub, [w:] Polski Stownik Biograficzny, t. 14, Warszawa 1968-1969, s. 362-363; W.Z. Brauer, Polskie piśmiennictwo położnicze XVIII wie$k u, c z .2$, „Archiwum Historii i Filozofji Medycyny oraz Historji Nauk Przyrodniczych” 1934, t. 14, s. 67-70.

${ }^{8}$ R. Steidele, Rafata Iana Steidele Anatomii, Chyrurgii, y Sztuki Babienia Extraordynarynnego publicznego Nauczyciela, Iego Cesarskich-Królewskich Mości Hiszpańskiego y Świętej Tróycy złączonych Szpitalów uprzywilejowanego Cerulika Księga O Sztuce Babienia z Przyłaczonemi Figurami w Wiedniu 1775 wydana. Teraz Przez Iakoba Kostrzewskiego Filozofyi y Medycyny Doktora, Iego Cesarskich Królewskich Mości w Królestwach Galicyi y Lodomeryi Cyrkutu Belzkiego Fizyka Na Oyczysty Ięzyk Przetłumaczona, Lwów 1777 (dalej: R. Steidele, Ksiega o Sztuce Babienia..., dz. cyt., s. 1777).

${ }_{9}$ M. Zieleniewski, Notatki do historyi akuszeryi w Polsce, księgarnia Henryka Natansona, Warszawa 1862, s. 86.

10 R. Steidele, Rafała Jana Steidele Chirurgii i Sztuki Babienia w powszechnym Chorych Domu Publicznego Nauczyciela Ksiega o Sztuce Babienia czyli dzieci odbierania, Z Przyłaczonemi Figurami po trzeci raz w Wiedniu wydana, która teraz Jakob Kostrzewski Filozofii i Medycyny w Akademii Wiedeńskiey Doktor, Jego Cesarsko- Królewskiey Mości w Królestwach Galicyi i Lodomeryi bywszy Prowincyalny Medyk i Fisyologii z Materya Medyka w Akademii Lwowskiey Publiczny Ordynaryjny Nauczyciel Na Oyczysty ięzyk przettómaczyt, Lwów 1786 (dalej: R. Steidele, Księga o Sztuce Babienia... 1786). Okoliczności powstania kolejnego tłumaczenia przedstawił w swoim artykule W.Z. Brauer, dz. cyt., s. 73-74.

${ }_{11}$ W.Z. Brauer, dz. cyt., s. 71; J. Krupiński, naczelny lekarz Galicji, w 1774 r. we Lwowie wydał pracę Osteologia, lub nauka o kosciach ciała człowieczego przez I.P. Iędrzeia Krupinskiego, w Królestwie Galicyi, y Lodomeryi nayiasnieyszey, y naypotę- 
(pierwszego wykładowcy położnictwa w Krakowie) wymieniany jest jako twórca nomenklatury położniczej ${ }^{12}$. Zauważyć jednak należy, że Kostrzewski napisał swą pracę (1774) na długo przed tym, jak Czerwiakowski objął katedrę (1779).

W 1786 r. ukazało się w Warszawie dzieło Jana Różańskiego, doktora medycyny i założyciela szkoły dla akuszerek w Mohylewie, pt. Sztuka Babienia, dzieło bardzo potrzebne nietylko odbierajacym po wsiach dzieci przy połogu, lecz też i wszystkim, którzy oddaleni będac, nie maja sposobności poradzenia sie i wzywania na ratunek $w$ tej sztuce biegłych, gdyż za jej pomoca pomyślnie ratować moga położnice częstokroć dla niedostatku należytej pomocy na wielkie wystawione niebezpieczeństwa, z rozmaitych autorów francuskich i niemieckich zebrana przez J. P. Różańskiego, w Lekarskiej sztuce doktora. Praca, nieco zmieniona, została wydana ponownie w $1792 \mathrm{r}^{13}$

Kolejne analizowane dzieło to Nauka położnicza z 1789 r. autorstwa Józefa Bergera de Lonchamps, studenta medycyny w Wilnie ${ }^{14}$. Jak sam pisze, wiedzę posiadł z francuskich poradników położniczych Anne-Amable Augiera Du Fota i Nicolasa Saucerotté'a. W Wilnie od 1785 r. istniała szkoła położnych założona przez Mikołaja Regniera, który wykładał położnictwo w Szkole Głównej Litewskiej ${ }^{15}$. Autor raczej stosował terminologię poznaną na wykładach, o czym mamy informację w tytule dzieła. Rok później ukazała się w Kaliszu Nauka

znieyszey cesarzowey rzymskiey pierwszego doktora krótko dla pożytku cyrulikow y powszechney potrzeby zebrana. Pisał w niej o braku prac $\mathrm{w}$ języku polskim i problemach językowych podczas pisania, s. VII-VIII, XXIX. Zob. też: W. Szumowski, Galicya pod względem medycznym za Jędrzeja Krupińskiego pierwszego protomedyka 17721783, nakł. Towarzystwa dla Popierania Nauki Polskiej, Lwów 1907, s. 159-160.

${ }_{12}$ Zob. przypis 3. Z. Słomko, E. Waszyński, dz. cyt., s. 36; M. Stawiak-Ososińska, Poczatki ksztatcenia akuszerek w Krakowie (1780-1805), „Studia Paedagogica Ignatiana” 2016, t. 19, nr 3, s. 50.

13 J. Różański, Sztuka Babienia, Dzieło Bardzo Potrzebne Nie tylko odbieraiacym po wsiach dzieci przy połogu, lecz też $i$ wszystkim, ktorzy oddaleni będac, nie maia sposobności poradzenia się $i$ wzywania na ratunek $w$ tey Sztuce biegłych, gdyż za iey pomoca pomyślnie ratować moga Położnice częstokroć dla niedostatku należytey pomocy na wielkie wystawiane niebeśpieczeństwa, Warszawa 1792. W tym samym roku ukazała się jego praca $O$ staranności koło kobiet od czasu rozwiazania onych, aż do końca połogu; Tudzież O różnych Chorobach, którym przez ten czasu przeciag, podlegaja Przez autora Sztuki babienia Nowo Przedrukowaney, Warszawa 1792.

${ }_{14} \mathrm{~J}$. Berger de Lonchamps, Nauka położnicza przez pytania i odpowiedzi po francusku napisana a teraz wyłożona po polsku przez Józefa Bergera de Lonchamps, ucznia medycyny, nauk wyzwolonych i filozofii doktora, korepetytora w anatomii w Szkole Głównej W.X.L za wiadomościa i aprobata profesorów medycyny i chirurgii w Akademii Wileńskiej w Wilnie w Drukarni J. K. Mości przy Akademii Roku 1789, Wilno 1789.

${ }^{15}$ Zob. przypis 3. 
Terminologia położnicza w polskich drukowanych podręcznikach akuszerii...

położna autorstwa Ludwika Perzyny ${ }^{16}$, najprawdopodobniej lekarza samouka z praktyką szpitalną, pracującego na terenie Dolnego Śląska i Wielkopolski ${ }^{17}$. Ostatnią chronologicznie pracą jest Krotka Nauka Dla Akuszerek po prowincjach za Nayłaskawsza Approbata i Zezwoleniem Departamentów Lekarskiego i Skarbowego J K Mći; P.N.M. przettómaczona $i$ wydana przez Jakuba Felixa de Michelis w Supraślu w 1800 r. Pochodzący z Prus autor był lekarzem Branickiej, a także chirurgiem w Białymstoku, gdzie założył szkołę akuszerek ${ }^{18}$.

Zatem przez 26 lat (1774-1800) powstało na ziemiach polskich sześć podręczników położniczych. Wydano je w różnych regionach: w Galicji, Wielkopolsce oraz na Litwie, Mazowszu i Podlasiu. Daje to możliwość analizy polskiego mianownictwa położniczego i stwierdzenia, które z terminów były powszechne w użyciu. Autorzy znali nomenklaturę z praktyki lekarskiej lub z wykładów (jako studenci lub jako organizatorzy kursów akuszerii) i używali jej w sposób zrozumiały dla adresatów podręczników (przyszli lekarze i akuszerki). Znamienne jest, że po reformie Kołłątajowskiej położnictwo zaczęto wykładać w obu szkołach głównych, ale podręcznik (napisany przez studenta) ukazał się tylko w Wilnie. Kolejnymi pracami związanymi z kręgami uniwersyteckimi był lwowski podręcznik J. Kostrzewskiego i jego tłumaczenia wiedeńskiego podręcznika położniczego.

Do analizy terminologii wykorzystano także podręczniki anatomii, gdyż zawierają opisy budowy części rodnych kobiety, dzięki czemu można było odnieść tę nomenklaturę do stosowanej w położnictwie. Były to m.in. podręczniki J. Krupińskiego ${ }^{19}$, L. Perzyny ${ }^{20}$, a także Anatomia to iest nauka poznania Części Ciała ludzkiego Teodora Weichardta (Kraków 1786). L. Perzyna w Nauce cyrulickiej zamieścił „Słownik anatomiczno-cyruliczny to iest: Wszystkich nazwisk i wy-

${ }^{16}$ L. Perzyna, Nauka położna krotko zebrana Cyrulikom położnym, iako też $i$ Babom, czyli Kobietom, przy rozwiazaniu rodzacych Położnic służacym dla wiadomości bardzo potrzebna na pytania i odpowiedzi rozłożona, Kalisz 1790.

17 Ks. A. Schletz, Ludwik Perzyna, lekarz, nauczyciel i wychowawca ludu 17421812, „Nasza Przeszłość. Studia z dziejów Kościoła i kultury katolickiej w Polsce” 1961, t. 13, s. 114. Por. W.Z. Brauer, dz. cyt., s. 93.

${ }^{18}$ E. Waszyński, Ginekologia..., dz. cyt., s. 359-369.

19 Zob. przypis 10.

${ }^{20}$ L. Perzyna, Anatomia krotko zebrana, Chcacym się uczyć Lekarskiey i Cyrulickiey nauki, lubo bez wyobrażeń, ale dokładnie i z praca napisana, Kalisz 1790; tegoż dwuczęściowe Nauki cyrulickiey krotko zebraney to iest: Nauki dla chcacych się uczyć Cyrulickiey umieiętnosci dokładnie napisaney, Kalisz 1792-1793. Druga wymieniona praca jest pierwszym podręcznikiem chirurgii wydanym w języku polskim, za: J. Skalski, Medycyna $w$ Polsce przedrozbiorowej, [w:] Dzieje medycyny w Polsce..., dz. cyt., Warszawa 2015, s. 118. 
razosłowów Anatomicznych, a niektórych tylko Cyrulicznych, w Łacinskim i w Polskim ięzyku napisany”. Ta ważna część pracy systematyzuje zakres wiedzy tego autora, także położniczej, i jest cennym źródłem wiedzy.

Słownictwo związane z ciążą i porodem znane jest z traktatów z XVI w. Zielnik Stefana Falimirza $(1543)^{21}$ zawiera takie zwroty, jak: poczęcie, płód, wstąpienie w brzemię [brzemię - etymologia: noszenie], panie brzemienne, brzemienna niewiasta, ciężka, pękata, żywot [brzuch, w którym znajduje się dziecko], macicza [etymologia: mać, matka] (,to iest miechierz w ktorim płod przemieszkawa"/ to jest miejsce, w którym płód zamieszkuje), Abors (,porzuczenie to iest niedonoszenie płodu”), zlężenie, rodzenie, porodzenie, wychodzenie. W „żywocie matczynym” płód otaczają trzy błonki: „wierzchnia i dwie spodnie”. Pierwsza błonka nazywa się „po łacinie secundina, po polsku łożisko”. Druga błonka „od pępka dziecięczego aż nadoł zawija dziecię”, ma wiele „zmarszków napodobieństwo flaków warzonych”, a trzecia „broni od dzieczeczego [dziecięcego] moczu y inszych wilkosci". Porody dzieli na dwa rodzaje: przyrodzone i słuszne obyczajem (czyli naturalne i we właściwym czasie), łaczne (pożądane) i lekkie oraz „nad obyczay przyrodzone" i w niesłusznym czasie, ciężkie (poród patologiczny i przedwczesny). Falmirz pisał o pomocy „babinej” przy porodzie i „zbyciu łożyska”. Pisał także o „tajemnym członku”, „tajemnym miestcu”, o „nizkim członku”, „nadolnym miestcu” oraz o przyrodzeniu, „rzeczach miesięcznych”, tj. krwawieniu miesięcznym. Dziecku przecina się po urodzeniu „pępek” ${ }^{22}$.

Od czasu ukazania się tego dzieła do poł. XVIII w. minęło ponad 200 lat. Język polski stopniowo wypierał łacinę z tekstów naukowych, ale zanim ukazały się analizowane podręczniki, przez cały czas istniała konieczność porozumiewania się lekarza/baby z pacjentką - wy-

${ }^{21}$ Część poświęcona porodom została zaczerpnięta wraz z ilustracjami z niem. dzieła pt. Der Swangern Frauwen und Hebammen Rosegarten Euchariusa Rösslina (1513). Także ono powstało w oparciu o wcześniejsze prace, wywarło jednak duży wpływ na położnictwo w całej Europie i doczekało się przekładu na wiele języków. Ta sama terminologia, jaka pojawia się u S. Falmirza, znajduje się w Zielniku Hieronima Spiczyńskiego (1542) i Herbarzu Marcina Siennika (1568) - księgi dotyczące rodzenia dzieci skopiowano z dzieła Falimirza.

${ }^{22}$ S. Falimirz, $O$ ziołach i o mocy ich, Kraków 1534; traktat „O Rodzeniu człowieczym" brak paginacji, wszystkie cytowania pochodzą z Capitulum 1, list. 16; capit. 2, list. 16; capit. 4, list. 19, 24, 28, 29; capit. 10, list. 35. Zob. szerokie omówienie terminologii medycznej w tej pracy: L.A. Jankowiak, Słownictwo medyczne Stefana Falimirza, t. 1, Poczatki polskiej renesansowej terminologii medycznej, Warszawa 2005. 
Terminologia położnicza w polskich drukowanych podręcznikach akuszerii...

tworzył się więc w „odmianie mówionej języka cały system leksyki, opisującej różne działy medycyny"23.

Większość autorów analizowanych prac miała świadomość problemów lingwistycznych i w większości z nich występują szeregi synonimiczne. J. Kostrzewski pisał we wstępie do swojej pracy o problemach w trakcie jej tworzenia. „Do wydania onej [książki] na język Ojczysty wszelkiego przyłożyłem starania, tylo sił moich natężałem, ażeby wyrazy sztuce właściwe językowi przyzwoite były, cudzych, i z różnych mieszanych ile możność dozwalała, unikałem, rzecz samą tak proście, tak jaśnie wyłożyłem, abym od wszystkich innych nauk nawet wcale nieświadomych był zrozumiany”. Używał pojęć powszechnie używanych lub też tworzył nowe: „nie małym trudem słów różnych wynajdować, onych znaczenie wykładać, wyrazu sztuce właściwych z najwyborniejszych, i najnowszych mówników wyczerpywać, tudzież nowe niekiedy wymyślać przymuszony byłem"24.

Ludwik Perzyna, motywując powstanie swojej pracy, pisał:

Dawnom i Ia także podobne rządał oglądać dzieło, alem się dokładnego w polskim Ięzyku doczekaś nie mogł. Przedsięwziąłem przeto sam, lubo krotko, ale dokładnie, tę Książeczkę o tey Nauce napisać, która sama z siebie nic nowego, ale wiela potrzebnego zawierać będzie ${ }^{25}$.

Fragment ten sugeruje, że wydający w Wielkopolsce Perzyna albo nie znał prac powstałych wcześniej we Lwowie czy Warszawie, albo też nie uważał ich za ważne.

Józef Berger de Lonchamps pisał w Przedmowie:

nasze wyrazy po znaczney części nie Polskie, któż wie, czy podobać się będą? I kto wie, czy pismo to obwinione nie będzie, jakoby chybiało przystoyności. [...] gdzie nam wyrazów oyczystych braknie, albo gdzie iuż lubo obce wyrazy, iednak osobom tey professyi dobrze są rozumiałe, nie zdawało się nowością słów zatrudniać Polskich Akkuszerów. Co do przystoyności w tey materii, niechay się tak dalece nie obraża zbyt delikatna skromność. Rzecz która się dla potrzeby wykłada, musi być

${ }^{23}$ L.A. Jankowiak, Z dziejów terminologii medycznej Słownictwo medyczne wieku XVI wobec XVII w. oraz pierwszej połowy XVIII w., „Studia z Filologii Polskiej i Słowiańskiej" 2009, t. 44, s. 76.

${ }^{24}$ J. Kostrzewski, Sztuka babienia ku nieuchronney dzieci przy porodzie odbieraiacych Potrzebie a niemniey y ku milemu rodzacych pożytkowi krotko y doskonale zebrana przez I.M.C.P. Jakoba Kostrzewskiego wyzwolonych nauk y filozofii doktora za dokładnym JCKM rozkazem, Lwów 1774, s. VIII, IX-XII.

${ }^{25}$ L. Perzyna, Nauka położna..., dz. cyt., s. 1-2: Uwiadomienia, brak paginacji. 
właściwemi sobie wyrazami tłumaczona, inaczey nie byłoby rozumiałości, a zatym i pożytku szukającycm z tąd nauki swojey dla służenia bliźnim ${ }^{26}$.

Lekarze musieli mieć zatem przykre doświadczenia, a opisywanie układu rodnego kobiet spotykało się z zarzutami nieprzyzwoitości. Miejsca wstydliwe powinny $\mathrm{w}$ powszechnej opinii pozostać nienazwane, by nie siać zgorszenia, co autor neguje. Podkreślił, że wybrał słownictwo najprzystojniejsze i najskromniejsze, ale i tak może zostać ono źle odczytane. Niektórzy autorzy, jak np. anatom T. Weichardt, pozostawali po prostu przy łacińskich nazwach. Weichardt pisał bowiem, że musiałby tworzyć nowe wyrazy, a w książkach naukowych i tak dominuje łacina ${ }^{27}$.

Istotną kwestią zdaje się określenie zasięgu terytorialnego prac i ich nakład. Państwo polskie powoli kurczyło się, by zniknąć ostatecznie z map, co nie ułatwiało wymiany myśli. Trudno określić zasięg terytorialny wymienionych prac, wiemy jednak, że częściowo ich odbiorcami byli słuchacze kursów położniczych (raczej z niedalekich okolic), poza tym problemem był powszechnie występujący analfabetyzm. Co do nakładu W. Brauer ustalił, że praca Kostrzewskiego raczej ukazała się $\mathrm{w}$ niewielkiej liczbie, a R. Steidelego w liczbie tysiąca egzemplarzy ${ }^{28}$. Problem z systematyzacją terminologii położniczej istniał jeszcze w XIX w., o czym świadczy powstanie w $1838 \mathrm{r}$. Słownika anatomiczno-fizyologicznego ułożonego przez drów Józefa Majera i Fryderyka Skobla professorów Wydziatu Lekarskiego w Uniwersytecie Jagiellońskim. Autorzy przez pięć lat zebrali i porównali wyrazy lekarskie, także położnicze, pojawiające się w dotychczasowej literaturze i starali się określić, które są najwłaściwsze ${ }^{29}$.

Tytuły prac wskazują jednoznacznie na adresatów, a także na słownictwo opisujące zajęcie odbierających porody. Wykonywaną przez nich czynność nazywano babieniem (Różański), sztuką babienia (Kostrzewski, Steidele, Różański), nauką położniczą (Berger de Lonchamps), nauką położną, Ars Obstetritia (Perzyna), sztuką położniczą

${ }^{26}$ J. Berger de Lonchamps, dz. cyt., brak paginacji, s. 4: Przedmowy.

${ }^{27}$ T. Weichardt, Anatomia to iest nauka poznania Części Ciała ludzkiego, Kraków 1786, s. 3.

${ }^{28}$ W. Brauer, dz. cyt., s. 71-72. Por. W. Szumowski, dz. cyt., s. 159.

${ }^{29}$ L.A. Jankowiak pisze, że synonimia w polskiej terminologii medycznej trwała do poł. XX w.; Synonimia w polskiej terminologii medycznej drugiej połowy XIX wieku (na podstawie Słownika terminologii lekarskiej polskiej z 1881 roku), Warszawa 2015, s. 15. Por. B. Urbanek, Ksztattowanie się specjalności lekarskich na ziemiach polskich w latach 1860-1914, Warszawa 2010, s. 208-211. 
Terminologia położnicza w polskich drukowanych podręcznikach akuszerii...

(Regnier, de Michelis). Należy dodać, że terminologia ta zmieniała się także u wykładowcy R. Czerwiakowskiego, który pierwszy zachowany rękopis, podręcznik dla studentów, zatytułował nauką połogowania (1780), a już rok później pisał o położnictwie i przy tej nazwie pozostał $^{30}$. Kobiety trudniące się tą sztuką nazywano babami (Perzyna, Różański), odbierającymi (Kostrzewski, Berger de Lonchamps), akuszerkami (de Michelis) lub kobietami położnymi (Perzyna), a mężczyzn cyrulikami, babcami (Steidele) lub akuszerami (Berger de Lonchamps). Kobieta rodząca to położnica. Gdy analizuje się prace chronologicznie, należy stwierdzić, że najstarsze określenie, czyli babienie, zostało ostatecznie wyparte przez położnictwo, a baba przez akuszerkę.

Podręczniki rozpoczyna opis układu rodnego kobiety, czyli „części niewieścich rodzeniu służących”, które według ówczesnej nomenklatury dzieliły się na części twarde (tj. kości) i miękkie (tj. narządy) tej klasyfikacji użył m.in. J. Kostrzewski ${ }^{31}$. Spośród części twardych wyróżnia się miednica, będąca częścią szkieletu, zwanego wówczas skeletem (Krupiński), budowlą kościaną lub kościoskładem (de Michelis). Etymologię podał L. Perzyna: „bo kości składające ten obwód, niby postać miednicy wyobrażają"32. W tłumaczeniu pracy R. Steidelego miednica o innych niż podane wymiarach nazywana jest „ciasną lub źle ukształconą" 33. Słowo miednica jest powszechnie używane przez wszystkich autorów, obok łacińskiego słowa Pelvis (Różański, Weichardt), ale już nazwy kości składających się na nią są różne. W XVIII-wiecznych podręcznikach w skład miednicy wchodziły następujące kości:

1) Os coxae, dwie kości bezimienne (dziś parzysta kość miednicza), zwano kośćmi bez imienia (Krupiński), lędźwi, kłąbowymi (Różański, Weichardt) lub z laciny Os Innominatum (Kostrzewski) albo Os Coxarum (Weichardt). Dzieliły się na:

a) Os ilium, kość biodrowa, zwana kiszkową (Kostrzewski, Krupiński, Berger de Lonchamps) i strzewną (Kostrzewski, Krupiński);

b) Os pubis, kość łonowa, zwana krokową (Kostrzewski, Krupiński, Berger de Lonchamps, Różański), haniebną (Kostrzewski, Krupiński, Perzyna), wstydliwą (Weichardt);

\footnotetext{
${ }^{30}$ Por. przypis 3.

${ }^{31}$ Por. J. Krupiński w podręczniku wydanym w tym samym roku: „O twardych (częściach - HK) uczy Osteologia, lub opisanie, y mowa o kościach. O miękkich uczą insze Anatomii części”; dz. cyt., s. XII.

${ }^{32}$ L. Perzyna, dz. cyt., s. 1.

${ }^{33}$ R. Steidele, Ksiega o sztuce Babienia..., dz. cyt., s. 31.
} 
c) Os ischii, kość kulszowa (Perzyna), zwana biodrową (Kostrzewski), siedzenia (Berger de Lonchamps, Michelis);

2) Os sacrum, kość kuprzasta (dziś krzyżowa), zwana kuprową (Berger de Lonchamps), Os Sacrum (Różański, Weichardt), świątniczą (Kostrzewski), krzyżową (Perzyna);

3) Os coccygis, kość ogonowa, zwana guziczną (Kostrzewski, Krupiński ${ }^{34}$.

Części miękkie kobiecego układu rodnego dzielono na wewnętrzne i zewnętrzne. Macica (łac. uterus) u wszystkich autorów jest najważniejszą wewnętrzną częścią tego układu, gdyż to w niej rozwija się płód. J. Kostrzewski obok dawnego terminu „żywot” pisał o „macicy"35 i u kolejnych autorów powszechna jest ta ostatnia nazwa. Słowo żywot w znaczeniu macica pojawiło się jeszcze w Nauce cyrulickiej L. Perzyny w haśle „Uterus”, a Berger de Lonchamps pisał o „otworze żywota” (vulva), czyli dzis. sromie. L. Perzyna w Anatomii opisywał, że składa się ona z trzech błonek (pospolita, myszkowa i nerwowa), a dzieli się na dno Fundus uteri i szyję Cervicem uteri ${ }^{36}$. Według J. Różańskiego, ,jest to proźna część wnętrzności, w której się płód zawięźnie, żywi i rośnie, aż do zupełnego złożenia się człowieka" ${ }^{37}$. W macicy wyróżniano m.in. szyjkę macicy, którą zwano klapkami macicznymi (Berger de Lonchamps), szyją macicy, uściem macicznym (Perzyna), gardłem macicy (Różański) ${ }^{38}$. Ścięgna utrzymujące macicę w miednicy to maciczne przepaski, ścięgna, więzy lub ligamenta ${ }^{39}$.

$\mathrm{W}$ budowie układu rodnego wymienione były obok macicy: pochwa, jajowody i jajniki. O ile termin macica był powszechny, o tyle dla pozostałych występuje wielowariantowość. Pochwa (Weichardt) to także pokrowiec (Perzyna), jajowody (tuba uterina) zaś to Tubae

${ }^{34} \mathrm{~J}$. Kostrzewski podał w przypisach etymologię nazw kości świątniczej oraz guzicznej: „Dlaczego kuprzastej kości wyrażone oraz imię Świętnicy nadane jest niezgadzają się Lekarscy Pisarze. Jedni: iż częściom sprośnym podległa oneż pokrywając, i jako święte tając ztąd początek wyrazu swego wzięła, mniemają. Drudzy; iż dla swej takowe imie nadane ma, rozumieją, ponieważ (jako mówią) dawni wszystkie wielkie rzeczy świętemi nazywali. [...] Imie guzicznej kości dla podobieństwa nadane jest: ogonowej, iż z tej u Zwierząt ogon wyrasta" (dz. cyt., s. 2-4). Tych samych określeń użył w wydanej w tym samym roku pracy J. Krupiński, dz. cyt., s. 13-14. Obie prace powstały we Lwowie.

35 J. Kostrzewski, „Macica czyli żywot na dno, szyję i uście dzieli się” (dz. cyt., s. 15).

${ }^{36}$ L. Perzyna, Anatomia..., dz. cyt., s. 87. Myszki w ówczesnej terminologii to dziś mięśnie.

37 J. Różański, Sztuka Babienia..., dz. cyt., s. 15.

38 J. Berger de Lonchamps, dz. cyt., s. 16-18; J. Różański, Sztuka Babienia..., dz. cyt., s. 27; L. Perzyna, Anatomia..., dz. cyt., s. 86.

${ }_{39}$ J. Kostrzewski, dz. cyt., s. 11; J. Różański, Sztuka Babienia..., dz. cyt., s. 15; L. Perzyna, Anatomia..., dz. cyt., s. 87. 
Terminologia położnicza w polskich drukowanych podręcznikach akuszerii...

Fallopianas, kanaliki błoniste, trąby maciczne (Kostrzewski, de Michelis, Perzyna), trąby Falloniusza (de Michelis), trąby Fallopa (Berger de Lonchamps), a strzępki jajowodowe zwane są u Lonchampsa „kąskami diabelskiemi” ${ }^{40}$. Według L. Perzyny, trąby maciczne mają na końcach „fałdowane niby listki Fimbria”, które w czasie obcowania nasienie przepuszczają do jajka, następnie je z gniazda (jajników) wyjmują i do macicy przenoszą ${ }^{41}$. Jajniki ${ }^{42}$ Ovaria/Testes Muliebres zwano wówczas jajecznikami (Kostrzewski, Steidele, de Michelis, Berger de Lonchamps), jajuszkami (Weichardt), z łac. ovaria (Weichardt), jądrami białogłowskimi (Kostrzewski, Krupiński), gniazdami jajecznymi (Kostrzewski, Perzyna). L. Perzyna pisał, że w „gniazdach” może znajdować się po 10-12 i więcej jajek Ovula/okrągłych pęcherzyków, a czasami po jednym, pęcherzyki zaś są pozawijane w plewkach ${ }^{43}$.

Zdaje się, że jeszcze większym problemem był brak określenia zewnętrznych części narządów płciowych kobiety, zwanych wstydliwymi. J. Kostrzewski zalecał położnym po porodzie przykrycie „wstydliwego członka” położnicy, a J. Różański „niewieściego przyrodzenia”44. Srom jest pojęciem współczesnym, a termin sromota/kobiecy członek pojawia się u L. Perzyny ${ }^{45}$. Do zewnętrznych części układu rodnego należą: 1) wzgórek łonowy (mons pubis), zwany także górką wstydliwego członka (Steidele), górą Wenusową (de Michelis), owłosionym podbrzuszem (Berger de Lonchamps);

2) wargi sromowe większe (labia majora pudendis), zwane wargami wielkimi wstydliwego członka (Steidele), wargami większymi łona (de Michelis);

3) wargi sromowe mniejsze (labia minora pudendis), zwane wodnymi wargami (Steidele) oraz powszechnie Nimfami. Interesująca jest etymologia nimf u J. Kostrzewskiego:

${ }^{40}$ J. Berger de Lonchamps, dz. cyt., s. 11.

${ }^{41}$ L. Perzyna, Anatomia..., dz. cyt., s. 88.

${ }^{42}$ Wówczas termin ,jajnik” nie był powszechny, podobnie jak w XIX w. - zob. uwaga: „W szkole krakowskiej używano nazwiska jajnik, jak to podobnież uczynił Jarocki W swojej «Zoologii». «Jaynik (ovarium)» Wyraz ten o tyle jest lepszy, o ile nie dopuszcza dwuznaczności, gdy tym czasem jajecznik znaczy także kołacz z jaj”, w: J. Majer, F. Skobel, Słownik anatomiczno-fizyologiczny ułożony przez drów Józefa Majera i Fryderyka Skobla professorów Wydziału Lekarskiego w Uniwersytecie Jagiellońskim, „Rocznik Wydziału Lekarskiego w Uniwersytecie Jagiellońskim” 1838, s. 188.

${ }^{43}$ L. Perzyna, Anatomia..., dz. cyt., s. 88-89.

${ }^{44}$ J. Kostrzewski, dz. cyt., s. 50; J. Różański, Sztuka Babienia..., dz. cyt., s. 70.

45 „Sromota kobieca lub łono (Vulva Pudendum), z obrostnicą, czyli hakiem (Mons veneris), pod nim znajduje się szczelina, czyli szpara Fissura ze znajdującymi się po obu stronach wargami (Labia vulvae), a jeszcze dalej grobelka, czyli taras między sromotą i pośladkowym otworem" (L. Perzyna, Anatomia..., dz. cyt., s. 82). 
Ponieważ starodawna bajeczność [...] nad wodami, i zrzódłami onych Boginie stróżujące jakoby (którym Greckie imie Nimfów nadał) przełożyła. Lekarscy więc pisarze dla podobieństwa niejakiego zrzedła mokrzu (rzadkiego moczu - HK), które spodniego otworu pęcherzyny przy marszczkach wyrażonych wytryskuje, marszczkom tym czyli wargom małym, iż mokrz wychodzący tak, by nóg nie zmoczył naprowadzają, podobnież imie Nimfów nadali ${ }^{46}$;

4) łechtaczka (clitoris), termin ten pojawiał się po raz pierwszy u J. Krupińskiego, później u J. Bergera de Lonchampsa ${ }^{47}$. U innych autorów terminu tego nie spotkamy. J. Kostrzewski pisał o języcz$\mathrm{ku}^{48}$, L. Perzyna w Nauce położnej o łaskotce, a w Nauce cyrulickiej o „Mentula muliebris”, czyli „korzeniu niewieścim, kiepie”49, z kolei T. Weichardt o członku wstydliwym kobiecym, który „się podnosi, i pod czas społeczeństwa z męszczyzną znaczne sprawuje łechtanie" ${ }^{50}$. L. Perzyna wymienił części kobiecego korzenia: 1) Główka, czyli żołądź, 2) Przedskurek, czyli Obrzezek, który żołądź w sobie chowa, 3) Boki, 4) Naprężające myszki [mięśnie], 5) Krwawe i nerwowe naczynia ${ }^{51}$. J. Berger de Lonchamps pisał jako jedyny o pomyłkach w przypadku „hermofrodyty”, gdy łechtaczka grubością i długością przypomina członek męski - mogło dojść do problemów z określeniem płci nowo narodzonego dziecka ${ }^{52}$;

5) błona dziewicza (hymen), zwana zamkiem panieństwa (Perzyna), błonką panieńską (Steidele), błonką hymen (Berger de Lonchamps);

6) ujście zewnętrzne cewki moczowej (ostium externum urethrae), zwane wówczas uściem przechodu mokrzu (moczu) (Kostrzewski), otworem urynowym (de Michelis), otworem kanału urynowego (Berger de Lonchamps), kanałem moczowym (Perzyna), uściem moczowej rurki (orificium ureterea, Perzyna).

W pracy J. Bergera de Lonchamps pojawiły się także terminy: „dwie marsczki formujące widełka” (współcześnie tzw. spoidła warg sromowych przednie i tylne oraz wędzidełko warg sromowych), dołek

${ }^{46}$ J. Kostrzewski, dz. cyt., s. 10-11. Por. J. Berger de Lonchamps (dz. cyt., s. 7, przypis a), który również wywodzi nazwę od bogiń.

${ }^{47}$ J. Krupiński, dz. cyt., s. 158; J. Berger de Lonchamps, dz. cyt., s. 7.

${ }^{48} \mathrm{~F}$. Wysocka pisze, że użył tego terminu niewłaściwie (Polska terminologia lekarska do roku 1838, t. 2, Anatomia - jednowyrazowe nazwy motywowane, Kraków 1994, s. 25).

${ }^{49}$ Kiep to staropolska nazwa sromu. J. Kostrzewski, dz. cyt., s. 10; L. Perzyna Nauka położna..., dz. cyt., s. 10; L. Perzyna, Nauka cyrulicka..., dz. cyt., cz. I, s. 149, 159.

${ }^{50}$ T. Weichardt, dz. cyt., s. 84 .

${ }^{51}$ L. Perzyna, Anatomia..., dz. cyt., s. 83-85.

52 J. Berger de Lonchamps, dz. cyt., s. 7-8, przypis b. 
Terminologia położnicza w polskich drukowanych podręcznikach akuszerii...

czołenkowaty, czyli dół łódeczkowaty przedsionka pochwy oraz spojenie wielkich warg. W układzie rodnym opisywano jeszcze krocze (perineum), zwane w podręcznikach międzykrokiem (Kostrzewski, Berger de Lonchamps), szwem (Kostrzewski), „między szwem” (Steidele), „mostkiem, czyli międzyszwem” (de Michelis), grobelką, tarasem, międzydupiem (Perzyna).

T. Weichardt w Anatomii podsumował opis układu rodnego:

Te wszystkie części następujący mieć się zdają pożytek: Pochwa maciczna przyjmuje członek męski, z którego wychodzące nasienie gdy się do macicy dostaje, przychodzi aż do pobocznych kanałów: tam wiszące nitki podnoszą się i Jajuszka w koło ściskają: jeden z małych w srzodku się znajdujących pęcherzyków odrywa się od błonki, która je łączy i przychodzi przez te poboczne kanały aż do macicy. Tu tedy zaczyna rosnąć, przemienia się w płód i przyszedłszy do doskonałości, w czasie rodzenia na świat wychodzi ${ }^{53}$.

W podobny sposób opisali to wcześniej J. Kostrzewski („Niewiasta poczyna, gdy nasienie Męskie jajko onejże trąbą maciczną z jajecznika zerwane do jamy Macicy zaprowadzone ożywia") ${ }^{54}$, L. Perzyna czy J. Różański (początkiem płodu jest „zarodne jajo znajdujące się w macicy”). Prace położnicze raczej ograniczają się do wspomnienia mimochodem, że do poczęcia dochodzi po spółkowaniu (Perzyna, Berger de Lonchamps i de Michelis). J. Krupiński pisał: „Białogłowa bądź lubieżnością bądź miłością potomstwa pobudzona, męszczyznę do spółkowania przypuszcza" 55 .

Ale nie zawsze spółkowanie kończyło się zapłodnieniem. Niepłodność tłumaczono m.in. brakiem miesiączkowania, z kolei jej zatrzymanie mogło być objawem poczęcia. U Krupińskiego, Perzyny i Bergera de Lonchampsa menstruacja to „czyszczenie miesięczne", a Kostrzewski, de Michelis i Berger de Lonchamps nazywają ją „płynieniem miesięcznym”, u Kostrzewskiego to także „odchód miesięczny” lub „miesiączka” ${ }^{56}$. Interesująca jest uwaga w Stowniku anatomiczno-fizjologicznym z XIX w.: „Pozostaje jeszcze wyraz mie-

53 T. Weichardt, dz. cyt., s. 88.

54 J. Kostrzewski, dz. cyt., s. 17; por. R. Steidele, Księga o Sztuce Babienia... 1777, s. 27.

55 J. Krupiński, dz. cyt., s. 185.

56 Tamże, s. 176; J. Kostrzewski, dz. cyt., s. 22; R. Steidele, Księga o Sztuce Babienia... 1777, s. 30; tegoż, Księga o Sztuce Babienia... 1786, s. 37; L. Perzyna, Nauka cyrulicka..., dz. cyt., s. 268; tegoż, Nauka położna..., dz. cyt., s. 24; J.F. de Michelis, dz. cyt., s. 26; J. Berger de Lonchamps, dz. cyt., s. 12. 
siączka, który, gdyby nie mniemana jego sprośność, uznalibyśmy za najlepszy" 57.

L. Perzyna uważa, że nie ma początkowo żadnych pewnych oznak brzemienności, a „obojętną” oznaką ciąży było m.in. odczucie kobiety,

gdy spółkowanie nad zwyczaj ją kontentowało, po którym za chwilę poczuła w ciele swoim niejakowąś ogrążkę [dreszcz/ciarki], dnia zaś następującego ciepło w żywocie czuła, lub gdy ją potym napadały nudności, wymioty, spinanie lub ból koło pempka, obrzask [wstręt] do mięsnych potraw, a mniejsza już czułość w dalszym spółkowaniu ${ }^{58}$.

Czas ciąży autorzy określają jako ciężarność (Kostrzewski, Steidele), brzemienność (Kostrzewski, Różański, de Michelis, Lonchamps) oraz ciężę, czyli zayście (Perzyna, jako jedyny pisał o „zajściu w ciążę"). J. Kostrzewski pisał o pierwiastce oraz o ciężarnej, co wydawało się jeszcze w II poł. XIX w. zabawnymi określeniami ${ }^{59}$. Klasyfikacja ciąży jest podobna w badanych podręcznikach. J. Kostrzewski wyróżnia ciążę prawdziwą (,gdy Niewiasta w Macicy swey Dziecie nosi”), fałszywą [„nie Dziecie, lecz co inszego jako zaśniad, płód nie donoszony (Mola), albo raczej sztuka mięsa miasto płodu, kule krwią lub wodą napełnione i tym podobne znajdują się rzeczy”] i zmieszaną (,gdy Macica oprócz prawdziwego Dziecięcia insze wyżej opisane rzeczy w sobie zawiera”). Ciążę prawdziwą w tłumaczeniu pracy Steidelego dzieli jeszcze na naturalną i nienaturalną. Jako jedyny J. Berger de Lonchamps klasyfikuje ciążę także według liczby dzieci na pojedynczą, podwójną, potrójną ${ }^{60}$.

Nie zawsze ciąża była przez kobietę donoszona, dochodziło do poronień. Termin ten występuje we wszystkich poradnikach, J. Kostrzewski pisał, że powszechnie mówiło się, iż kobieta „płód postradała”. U Perzyny pojawia się także nazwa ronienie, jako „rodzenie w nieprzyzwoitym czasie”, a płód wcześnie urodzony nazywa „potyranym”, z kolei urodzony o czasie „dzieckiem urodzonym Faetus”61.

Podczas ciąży funkcjonuje szereg struktur morfologicznych określanych mianem popłodu (adnexa fetalia). Zalicza się do niego: łoży-

57 J. Majer, F. Skobel, dz. cyt., s. 164.

${ }^{58}$ L. Perzyna, Nauka położna..., dz. cyt., s. 23.

${ }^{59}$ R. Steidele, Księga o Sztuce Babienia... 1777, s. 26; R. Steidele, Księga o Sztuce Babienia... 1786, s. 160; M. Zieleniewski, dz. cyt., s. 86. Termin pierwiastka pojawił sie już w 1564 r. u Jana Mączyńskiego w Lexicon latino-polonicum, za: J. Majer, F. Skobel, dz. cyt., s. 211.

${ }^{60}$ J. Berger de Lonchamps, dz. cyt., s. 14.

${ }^{61}$ L. Perzyna, Anatomia..., dz. cyt., s. 93. 
Terminologia położnicza w polskich drukowanych podręcznikach akuszerii...

sko, pępowinę oraz błony płodowe ${ }^{62}$. W XVIII w. pisano, że płód otoczony jest błonami, zwanymi także skórkami (Kostrzewski) i pliwkami (Różański). Wymieniano dwie błony: Amnios (wewnętrzna) i Chorion (zewnętrzna) ${ }^{63}$. Amnios w ówczesnej nomenklaturze to błona płaszczykowa (R. Steidele, Lonchamps), błona owcza (Perzyna, Różański, de Michelis) lub przypotok (Kostrzewski, Krupiński), a „kobiety wodną błoną, Łożyskiem, lub miejscem, lub owczą błoną nazywać zwykły” (Perzyna). Płód miał wolno pływać w wodach, zwanych także ciekłością i lipkim sokiem (Perzyna) ${ }^{64}$. Kostrzewski i Berger de Lonchamps nazywają charion błoną żylistą, Perzyna błoną żylastą, Różański zaś pisał, że „zewnętrzna pliwka jaja nazywa się żyławą”. J. Kostrzewski zaznaczył, że w porodzie bliźniąt każde ma swoją błonę owczą, a jeśli mają zrośnięte łożyska, wówczas mają wspólną „skórkę żylistą"

Po zapłodnieniu zarodek zagnieżdża się w ściance macicy. Między innymi z błony żylastej tworzy się łożysko, łac. placenta (Kostrzewski, Czerwiakowski, Berger de Lonchamps), zwane przez odbierające poporodem (jak pisał Kostrzewski), a przez innych autorów miejscem (Różański, Berger de Lonchamps), brzemieniem czy też plackiem (Perzyna). L. Perzyna pisał: „placek jest to owa, żylasta łata, zaraz po urodzeniu dziecka z miejscem wraz odchodząca, podobieństwo do placka mająca [...] placek ten nazywają także niektórzy brzemieniem"66. Berger de Lonchamps dodał, że niekiedy brzeg łożyska łączy się z powrozkiem pępkowym, i takie łożysko nazywano „rakietą"67.

Pępowinę (de Michelis, Czerwiakowski) zwano także powrozkiem pępkowym (Steidele, Lonchamps), powrozkiem pępowinowym (Kostrzewski), Funiculus umbilicalis pępkowym flakiem (Perzyna, Nauka cyrulicka, Anatomia), pempkowym flakiem, czyli sznurem (Perzyna, Nauka położna), sznurem pępkowym (Czerwiakowski, Różański, Lon-

${ }^{62}$ Położnictwo i ginekologia, G.H. Bręborowicz (red.), t. 1. Położnictwo, Warszawa 2015, s. 17.

${ }^{63}$ We współczesnym położnictwie używamy terminów owodnia (amnios) i kosmówka (charion). Amnios otacza płód pęcherzem płodowym stanowiącym szczelnie zamknięty worek wypełniony płynem owodniowym, a kosmówka osłania ciało zarodka.

${ }^{64}$ Warto zauważyć, że niektórzy pisali także o występowaniu wód fałszywych, np. R. Steidele, Księga o Sztuce Babienia... 1777, s. 83-84.

${ }^{65}$ R. Steidele, Księga o Sztuce Babienia... 1786, s. 307. Dziś mówimy o ciąży bliźniaczej dwujajowej i jednojajowej.

${ }^{66}$ L. Perzyna, Nauka położna..., dz. cyt., s. 14-15. Por. tegoż, Nauka cyrulicka..., dz. cyt., s. 177; podobnie pisał w Anatomii..., dz. cyt., s. 90. T. Weichardt pisał: „placenta czyli placek lub powszechnie u nas tak zwane Mieysce” (dz. cyt., s. 89).

${ }^{67}$ J. Berger de Lonchamps, dz. cyt., s. 21. Według współczesnej terminologii autor opisał brzeżny przyczep pępowiny. 
champs, Regnier) lub pępkiem (de Michelis) ${ }^{68}$. Wszyscy autorzy pisali, że pępowina składa się z dwóch żył pulsowych i jednej krwistej.

Podręczniki zalecają badanie położnicy przed zbliżającym się porodem. Zalecano więc zakasanie (Perzyna), rewidowanie, macanie (R. Steidele, Berger de Lonchamps), doświadczenie (R. Steidele) czy też z franc. tuszowanie niewiasty (de Michelis). Poród zwano zlężeniem (Różański), porodzeniem (Kostrzewski), połogiem (Berger de Lonchamps), rodzeniem (Berger de Lonchamps, de Michelis). Dokonywano klasyfikacji porodu ze względu na poziom skomplikowania, czas oraz ułożenie dziecka w drogach rodnych. Współcześnie mówimy o porodach prawidłowych/fizjologicznych, nieprawidłowych i patologicznych, wówczas o porodach naturalnych i ciężkich/trudnych/ nienaturalnych. Ze względu na długość ciąży klasyfikowano je na porody o czasie przyzwoitym (ok. 40 niedziel), niewczesne (między 30 a 40 niedzielą) oraz poronienie (przed 30 niedzielą) ${ }^{69}$ lub ze względu na czas ich trwania na prędkie i długotrwające. Berger de Lonchamps nazwał poród, podczas którego wody płodowe odejdą znacznie wcześniej, niż nastąpi akcja porodowa, „rodzeniem na sucho”70. Porody zaś klasyfikował na takie, które odbywają się siłami matki, z pomocą odbierającej lub z użyciem instrumentów ${ }^{71}$.

Zwiastunami zbliżającego się porodu były bóle, mogły to być bóle prawdziwe lub fałszywe - akuszerka powinna umieć je odróżnić. Niektórzy autorzy wspominali o bólach pierwiastkowych, zwanych „,posłami”. J. Kostrzewski w swoim tłumaczeniu podręcznika Steidelego wspomniał, że bóle poprzedzające „odbierające nazywają wlekące”72. L. Perzyna klasyfikował bóle na pierwiastkowe, czyli pierwsze oraz prawdziwe i fałszywe, a J.F. de Michelis rozróżniał wśród bóli prawdziwych, zwanych kurczowymi: „1) bóle przepowiadające (tzw. „posełki”, krótko trwają), 2) usposabiające rodzenie, 3) prawdziwe bóle rodzące oraz 4) przerzynające"”3.

Interesującą definicję porodu zawarł w Anatomii L. Perzyna: macica płód, „gdy już zupełnie swojej pory dojdzie, mocą swych własnych kurczących się żyłek czyli raczej myszek, z siebie wypycha i na świat wydaje"74. Akcji porodowej towarzyszy odejście wód płodowych, czyli

\footnotetext{
68 J.F. de Michelis, dz. cyt., s. 50-51, 68.

69 Tenże, dz. cyt., s. 41. Por. R. Steidele, Księga o Sztuce Babienia... 1777, s. 86-87.

70 J. Berger de Lonchamps, dz. cyt., s. 22.

71 Tamże, s. 27.

72 R. Steidele, Księga o Sztuce Babienia... 1777, s. 69

${ }^{73}$ L. Perzyna, Nauka położna..., dz. cyt., s. 40-41; J.F. de Michelis, dz. cyt., s. 44.

${ }^{74}$ L. Perzyna, Anatomia..., dz. cyt., s. 89. Myszek, czyli mięśni.
} 
Terminologia położnicza w polskich drukowanych podręcznikach akuszerii...

wylanie się wody. „Woda zbiera” - tak według Perzyny powinno się mówić, gdy woda $\mathrm{z}$ błoną $\mathrm{z}$ macicy zaczyna występować $\mathrm{w}$ miednicę, a gdy woda w znacznej ilości w ,pokrowiec maciczny napędzoną zostanie”, mówi się, że „woda szeroko zebrała” - co jest oznaką lekkiego rozwiązania. Niewielki strumień wody („woda ukradkiem odchodzi”) może oznaczać z kolei ciężki połóg75.

Wszystkie podręczniki opisują poród fizjologiczny, ale nacisk kładą na opisy porodów patologicznych. Porody ciężkie definiowane były pozycją dziecka w kanale rodnym, a więc dziecko zwrócone twarzą, uszami, tyłem głowy, szyją, łopatkami, ramionami, bokiem ciała, grzbietem, czyli plecami, piersią, brzuchem, zadkiem/ pośladkami, kolanami i nogami. Zdawano sobie sprawę z trudności i niebezpieczeństwa takiego ułożenia dziecka zarówno dla matki, jak i dziecka. Zalecano odbierającym obrót dziecka w kanale rodnym, a w przypadku, gdy matka zmarła w trakcie porodu, jak najszybsze wydobycie dziecka z brzucha przez „płatanie cesarskie” lub operację cesarską (Perzyna), zwaną także operacją Cesareo (Różański). Zostawiano to jednak chirurgom, a nie akuszerkom, a instrumentów należało użyć w wyjątkowych sytuacjach ${ }^{76}$. Pisano także o śmierci pozornej noworodka, zalecając próby ich ratowania przez pocieranie ciała oraz wdmuchiwanie powietrza w usta (Steidele, Rożański, Perzyna, Lonchamps) ${ }^{77}$.

Ostatnim etapem porodu był poród łożyska, który miał odbyć się samoistnie - tzw. poporód ${ }^{78}$, ale kiedy do niego nie dochodziło, wówczas akuszerka miała delikatnie ciągnąć pępowinę jedną ręką, a drugą wysunąc łożysko ${ }^{79}$. Zdawano sobie sprawę, że nieumiejętne postępowanie $\mathrm{w}$ takich przypadkach może doprowadzić do krwotoku, a w efekcie do śmierci kobiety.

$\mathrm{Na}$ koniec analizy terminologii położniczej uwagi o urodzonym dziecku: J. de Michelis pisał, że „zdarzać się zwykło czasem, iż znaj-

${ }^{75}$ Tegoż, Nauka położna..., dz. cyt., s. 71.

${ }^{76} \mathrm{~W}$ ówczesnym położnictwie wyróżniano dwa nurty: zachowawczy, reprezentowany przez wiedeńską szkołę, nakazujący wykorzystanie w porodzie sił natury i ograniczanie użycia narzędzi (np. kleszczy) do sytuacji wyjątkowych oraz nurt postępowy, czynny, zalecający operacje porodowe. W Polsce dominował raczej nurt zachowawczy. E. Waszyński, Ginekologia..., dz. cyt., s. 371. Por. W. Brzeziński, Medycyna zabiegowa, [w:] Historia medycyny, T. Brzeziński (red.), Warszawa 2014, s. 161-163.

77 Więcej na ten temat w pracy: T. Siody, Historia ożywiania noworodków w Polsce, Poznań 2015.

${ }^{78}$ J. Kostrzewski, dz. cyt., s. 39.

${ }^{79}$ Było to nowoczesne podejście do zagadnienia, wcześniej zalecano jak najszybsze wyciągnięcie łożyska, por. W. Szumowski, dz. cyt., s. 289-290. 
dują się na nim [urodzonym dziecku] błony, w których było zawarte, a które Koszulką lub czepcem nazywać zwykli" ${ }^{80}$. L. Perzyna precyzuje, że u urodzonych chłopców ten kawał błony nazywa się szyszak Galea, a u dziewcząt czepek ${ }^{81}$.

Jakie wnioski wypływają z analizy słownictwa zawartego w podręcznikach z końca XVIII w.? Dostrzec można wielowariantowość terminologii położniczej. Najstarszą pracą położniczą była Sztuka babienia Jakuba Kostrzewskiego i to jemu należy się palma pierwszeństwa co do spisania i stworzenia słownictwa położniczego. Trudno jednoznacznie ocenić, które z terminów położniczych stosowanych w XVIII w. były używane wśród lekarzy oraz bab i zostały po prostu spisane, a które były terminami nowymi lub zastępującymi inne, uważane za np. nieprzyzwoite. $\mathrm{Z}$ pewnością wiele nazw pochodziło $\mathrm{z}$ języka potocznego, gdyż autorzy niekiedy przytaczają zwroty używane przez odbierające porody kobiety ${ }^{82}$. Stosowane nazewnictwo wskazuje, że pewne terminy były używane powszechnie, jak np. płód, macica, łożysko czy miednica, inne u niemal każdego autora były odmienne i ewoluowały jeszcze w XIX w.

\title{
Summary \\ Maternity terminology in Polish printed textbooks of midwifery and anatomy from second half of the eighteenth century
}

\begin{abstract}
In the 18th century, many maternity handbooks were created in the Polish Commonwealth, mainly for women. These were not original works, but rather translations or borrowings from Western European tractates. However, their authors had to solve the problem of lacking obstetric terms in the Polish language. Many expressions of the female parts were considered indecent, and the textbooks were considered inappropriate for women. The first author who undertook the task of using maternity terminology was Jakub Kostrzewski. In his works, many expressions were repeated (macica/uterus, płód/fetus, miednica/pelvis) after precursor from 16th century, but some were just forming, such as pochwa/vulva, techtaczka/ clitoris, jajowody/fallopian tubes. The maternity terminology was floating and occurred different forms in individual authors. Other authors of the textbooks were: Raphael Steidele, Jan Różański, Józef Berger de Lonchamps, Ludwik Perzyna and Jakub Felix de Michelis. This article is based mainly of sources from $18^{\text {th }}$ century.
\end{abstract}

Keywords: midwifery; polish maternity terminology; history of medicine; 18th century

${ }^{80}$ J.F. de Michelis, dz. cyt., s. 62. Dziś powiedzenie: „w czepku urodzony”.

${ }^{81}$ L. Perzyna, Anatomia..., dz. cyt., s. 91.

82 Por. R. Wierzbicki, dz. cyt., s. 57. 